\title{
PENGELOLAAN PENDIDIKAN KEAGAMAAN HINDU \\ DI YAYASAN PASRAMAN GURUKULA BANGLI PROVINSI BALI
}

\author{
Ni Komang Sutriyanti \\ Institut Hindu Dharma Negeri Denpasar \\ nikomangsutriyanti@gmail.com
}

\begin{tabular}{|c|c|}
\hline \multicolumn{2}{|l|}{$\begin{array}{l}\text { Riwayat Jurnal } \\
\text { Artikel diterima: } \\
\text { Artikel direvisi: } \\
\text { Artikel disetujui: }\end{array}$} \\
\hline $\begin{array}{l}\text { Kata Kunci: } \\
\text { Pengelolaan } \\
\text { Pendidikan } \\
\text { Keagamaan Hindu } \\
\text { Pasraman Gurukula }\end{array}$ & $\begin{array}{l}\text { Abstrak } \\
\text { Setiap organisasi memiliki aktivitas-aktivitas pekerjaan tertentu dalam } \\
\text { rangka mencapai tujuan organisasi. Dalam usaha pencapaian tujuan } \\
\text { pendidikan, peran manajemen sangat dibutuhkan dalam } \\
\text { penyelenggaraan pendidikan.Bahkan manajemen memiliki kedudukan } \\
\text { dan posisi yang sangat sentral dalam keseluruhan proses pendidikan } \\
\text { serta merupakan syarat mutlak dan bagian yang tak terpisahkan dari } \\
\text { pendidikan itu sendiri, karena manajemen sangat penting, maka } \\
\text { menjadi tanggung jawab semua pihak yang terkait dalam proses } \\
\text { penyelenggaraan pendidikan. Berkaitan dengan penyelenggaraan } \\
\text { pendidikan, Peraturan Menteri Agama Republik Indonesia Nomor } 56 \\
\text { tahun } 2014 \text { tentang Pendidikan Keagamaan Hindu yang didalamnya } \\
\text { mengelola jalur pendidikan formal dan nonformal Hindu dalam wadah } \\
\text { pasraman tentu membutuhkan pedoman dalam pengelolaan } \\
\text { pendidikan tersebut baik dari segi perencanaan, pengorganisasian, } \\
\text { pelaksanaan maupun pengawasannya. Yayasan Pasraman Gurukula } \\
\text { Bangli merupakan yayasan yang mengelola lembaga pendidikan } \\
\text { keagamaan bernuansa Hindu yang saat ini dalam proses perubahan } \\
\text { status menjadi yayasan pendidikan keagamaan Hindu. Disamping itu } \\
\text { juga yayasan tersebut satu-satunya yayasan yang ada di Bali dan } \\
\text { bahkan di Indonesia yang mengelola dua jalur pendidikan bernuansa } \\
\text { Hindu yaitu pendidikan formal yang terdiri dari SMP dan SMA } \\
\text { Gurukula Bangli dan pendidikan nonformal berupa Pasraman } \\
\text { Gurukula Bangli serta siswa Gurukula berasal dari anak-anak yang } \\
\text { kurang mampu dari seluruh Indonesia yang beragama Hindu. } \\
\text { Penyelenggaraan pendidikan tentu mengalami kendala-kendala baik } \\
\text { itu kendala internal maupun kendala eksternal. Bertitik tolak dari } \\
\text { fenomena tersebut di atas peneliti tertarik mengkaji lebih jauh } \\
\text { mengenai Manajemen Pendidikan Keagamaan Hindu dengan judul } \\
\text { "Pengelolaan Pendidikan Keagamaan Hindu di Yayasan Pasraman } \\
\text { Gurukula Bangli Provinsi Bali". }\end{array}$ \\
\hline
\end{tabular}




\begin{tabular}{|l|l|}
\hline Keyword: & $\begin{array}{l}\text { Abstract } \\
\text { Management of } \\
\text { Easraman Every organization has certain work activities in order to achieve } \\
\text { organization goals. In line to achieve an educational goals, the role of } \\
\text { management is needed in implementation of education. Even } \\
\text { management has a position and central position in the whole process } \\
\text { of education and belong to absolute requirement and an integral part } \\
\text { of education itself, because management is very important, then it is } \\
\text { the responsibility of all parties involved in the process of organizing } \\
\text { education. Related in implementation of education, Regulation of } \\
\text { Religion Ministry of Republic Indonesia Number 56 Year 2004 about } \\
\text { Hindu Religious Education contained it manages the formal and non- } \\
\text { formal Hindu education in a pasraman place certainly requires } \\
\text { guidance in the management of Education, in terms of planning, } \\
\text { organizing, implementing and monitoring. Orphanage of Pasraman } \\
\text { Gurukula Bangli is orphanage which is managed Hinduism of religon } \\
\text { education institution which is currently processing of changing its } \\
\text { status to become an orphanage of Hinduism religious education. } \\
\text { Beside that, the orphanage is also the only one in Bali and even in } \\
\text { Indonesia which is managed into two Hinduism education ways such } \\
\text { as formal education consist of Junior High School and Senior High } \\
\text { School Gurukula Bangli and non formal education as Orphanage } \\
\text { Gurukula Bangli and Gurukula Students come from over not children } \\
\text { from all over Indonesia for Hinduism. The implementation of } \\
\text { education absolutely get whether internal and external trouble. Based } \\
\text { on that phenomenon the researcher is interested to find about Hinduism } \\
\text { education management entitled "Management of Hinduism education } \\
\text { at Orphanage of Pasraman Gurukula Bangli of Bali Province". }\end{array}$ \\
\hline
\end{tabular}

\section{Pendahuluan}

Pasraman merupakan salah satu Pendidikan non formal yang bertujuan untuk membantu pelaksananan Pendidikan Agama Hindu dan Budi Pekerti yang menekankan pada pertumbuhan sikap dan keterampilan. Nn Pendidikan Agama dan Budi Pekerti yang diberikan di sekolah lebih menekankan pada penguasaan pengetahuan. Pasraman mempunyai fungsi yang sangat strategis dalam membantu pemerintah untuk menumbuhkan karakter peserta didik yang baik. pelaksanaan pendidikan pasraman dan agar lembaga pendidikan ini mampu bersaing dengan lembaga pendidikan modern yang telah berkembang pesat saat ini, maka masih perlu usaha maksimal dari para pengelola lembaga pendidikan pasraman ini, baik menyangkut aspek manajemennya, aspek kurikulumnya, strategi yang diterapkan, maupun berbagai infrastruktur pendukung pendidikan pasraman (Suda, 2017). Guru memegang peranan penting dalam proses pembelajaran dan dalam suatu lembaga pendidikan, guru menjadi komponen yang sangat menentukan berkualitas dan tidaknya lembaga pendidikan. 
Sebab mengacu pada uraian bahwasanya betapapun bagusnya regulasi kebijakan pendidikan dan kurikulum, jika tidak diimbangi dengan tenaga pendidik guru yang profesional, maka proses pendidikan tidak dapat berjalan dengan baik (Sutriyanti, 2017).

Pendidikan pasraman mampu mengakomodasi segala macam nilai karakter yang universal.Nilai-nilai karakter yang universal selalu diajarkan dalam materi lokal dan agama Hindu yang sarat dengan nilai-nilai universal. Secara konotatif, pendidikan karakter, seperti mengacup pada Russell Williams, yakni seperti "otot", di mana "otot-otot" karakter akan menjadi lembek apabila tidak pernah dilatih, dan akan kuat dan kokoh kalau sering dipakai. Seperti halnya binarawan yang terus-menerus berlatih membentuk ototnya, maka "otot-otot" karakter juga akan terbentuk dengan praktik-praktik latihan yang akhirnya menjadi kebiasaan atau habit. Jika karakter menjadi kebiasaan maka seseorang secara otomatis akan melaksanakannya. Oleh karena itu, penerapan pendidikan agama Hindu berbasis pasraman selalu menekankan pada konsep mengalami agar siswa terbiasa megalami.

Berangkat dari gagasan tersebut, pembelajaran pada Yayasan Pasraman Gurukula Bangli sesungguhnya mengarah pada pembelajaran holistik yang nantinya melahirkan SDM Hindu yang mampu memiliki pengetahuan secara menyeluruh.Sebagaimana hal tersebut sejalan dengan taksonomi dari Bloom (Sukardjo, 2013) bahwa capaian pembelajaran hendaknya menekankan pada aspek afektif atau perilaku, kognitif atau kemampuan intelektual dan psikomotorik atau aspek keterampilan yang dimiliki dalam pembelajaran. Pendidikan keagamaan Hindu yang terdapat di Yayasan Pasraman Gurukula Bangli terdiri dari 4 satuan pendidikan, yaitu 1) TK Pra Vidyalaya Gurukula Bangli, 2) SMP Gurukula Bangli, 3) SMA Gurukula Bangli dan 4) Pasraman Gurukula Bangli.Keempat satuan pendidikan tersebut bernaung dibawah Kemendikbud dan Kemenag. Dan pengelolaan pasraman di Yayasan Gurukula Bangli merupakan hal yang sangat penting karena mempengaruhi seluruh aspek dan sistem Pendidikan yang ada dalam pasraman.

\section{Pembahasan}

\section{Pengelolaan Pendidikan Keagamaan Hindu di Yayasan Pasraman Gurukula Bangli}

Pengelolaan pendidikan keagamaan merupakan serangkaian kegiatan merencanakan, mengorganisasikan, memotivasi, dan mengawasi segala upaya di dalam mengatur dan mendayagunakan sumber daya manusia, sarana dan prasarana untuk mencapai tujuan pendidikan keagamaan. Pendidikan keagamaan Hindu yang terdapat di Yayasan Pasraman 
Gurukula Bangli terdiri dari 4 satuan pendidikan, yaitu 1) TK Pra Vidyalaya Gurukula Bangli, 2) SMP Gurukula Bangli, 3) SMA Gurukula Bangli dan 4) Pasraman Gurukula Bangli.Keempat satuan pendidikan tersebut bernaung dibawah Kemendikbud dan Kemenag.Adapun ruang lingkup pengelolaan pendidikan keagamaan Hindu di Yayasan Pasraman Gurukula Bangli dapat dijelaskan sebagai berikut :

\section{a. Pengelolaan Kurikulum}

Pengeloalan kurikulum pada Yayasan pasraman Gurukula Bangli lebih kepada pengkombinasian kurikulum dengan memadukan antara kurikulum dengan muatan nasional dengan kurikulum pasraman yang lebih bermuatan lokal dan agama. Dengan demikian ada semacam integrasi yang kuat antara keduanya, sehingga ada sinergisme yang kuat, dan penjabarannya tentu melalui proses pembelajaran yang dikelola berdasarkan atas acuan kurikulum tahun 2013, yakni berkaitan dengan tugas guru, dan berkaitan dengan proses pembelajaran (Sutirna, 2015). Pengelolaan yang mendasarkan pada acuan kurikulum nasional tentunya sasaran pembelajaran yang dituju adalah sebagai upaya untuk meningkatkan SDM Hindu yang berkualitas didasari atas ajaran agama Hindu.

Melalui pengeloalaan yang demikian, proses pembelajaran terimplementasikan dengan baik untuk menumbuhkan sikap disiplin.Disiplin banyak digunakan di sekolah untuk mengontrol tingkah-laku siswa (termasuk guru dan pegawai tata-usaha) agar tugas-tugas sekolah berjalan dengan optimal. Sesungguhnya menegakkan disiplin tidak bertujuan untuk mengurangi kebebasan/kemerdekaan, tetapi justru sebaliknya untuk memberikan kemerdekaan yang lebih besar dalam batas kemampuannya masing-masing, yaitu keseimbangan antara tuntutan individu dengan tuntutan masyarakat (Rusman, 2011).

Pembiasaan berdisiplin di Yayasan Pasraman Gurukula Bangli mempunyai pengaruh positif bagi kehidupan siswa di masa mendatang, karena disiplin yang dipatuhi secara sadar demi kebaikan diri sendiri dan kebaikan bersama lama-kelamaan akan menjadi suatu kebiasaan yang baik menuju kearah disiplin diri (self discpline). Disiplin diri ini akan tumbuh dengan baik dalam suatu suasana dimana antara guru dan siswa dalam Yayasan Pasraman Gurukula Bangli terjalin sikap persahabatan yang berakar pada dasar saling hormat-menghormati serta saling percaya-mempercayai.

Pengeloalaan kurikulum pada Yayasan Pasraman Gurukula Bangli hadir sebagai origin point dalam penyelenggaraan pendidikan, sehingga dalam dalam proses pembelajaran kurikulum selalu dijadikan basis edukatif di dalam mengupayakan tercapainya tujuan 
pembelajaran (pendidikan)(Sutriyanti, 2017). Berkenaan dengan hal itu, banyak para ahli pendidikan menjelaskan bahwa pembelajaran merupakan "implementasi” kurikulum (Dimyati dan Mujiono,2013:286). Mendasarkan pada terma tersebut, dapat dinyatakan bahwa kurikulum dengan pembelajaran memiliki pertautan yang koheren, bahkan identik. Proses pembelajaran selayaknya "cermin" isi kurikulum dan pantulan cermin adalah out put dari proses pembelajaran.

Yayasan Pasraman Gurukula Bangli sebagai lembaga pendidikan yang bernuansa Hindu. Dalam pengembangan program pendidikannya, disamping mengembangkan pendidikan nasional juga berkewajiban membina peserta didik untuk memahami dan mendalami nilai-nilai kebudayaan Hindu melalui pasraman (ekstra kurikuler), yang nantinya mampu mencetak generasi-generasi Hindu memiliki keterampilan khusus menurut fungsi dan kemampuan masing-masing dan mampu mempertahankan kebudayaan Bali yang dijiwai oleh agama Hindu.

Selanjutnya untuk menunjang keberhasilan dari program tersebut di atas sangat memerlukan adanya dukungan dan kerjasama dari masyarakat maupun dukungan dari instansi pemerintah serta swasta baik moril maupun materiil, guna kelangsungan kegiatan secara terusmenerus (kontinyu) yang dapat menghasilkan siswa yang berwawasan budaya dan memiliki keterampilan pada bidangnya masing masing untuk dapat dan bisa menunjang kelangsungan hidupnya (Life Skill). Sasaran dari kegiatan ini adalah peserta didik (siswa Hindu) tingkat TK, SMP dan SMA/SMK di lingkungan Yayasan Pasraman Gurukula Bangli dan sekolah-sekolah umum lainnya di lingkungan wilayah Kota Bangli. Para peserta dipilih yang memiliki minat, bakat dan kemampuan serta berpotensi tinggi di bidang seni budaya.Adapaun bidang kegiatan atau jenis-jenis kegiatan ektra kurikuler yang di selenggarakan oleh Yayasan Pasraman Gurukula Bangli meliputi Dharmagita dan Seni Musik, Seni Tabuh dan Tari, Seni Rupa / Lukis, Bidang Nyastra, Bidang Dharma Wacana, Bidang Upakara, Bidang Yoga

\section{b. Pengelolaan Sumber Daya Manusia (SDM)}

Pengelolaan sumber daya manusia/personel adalah segenap proses penataan yang bersangkut paut dengan masalah memperoleh dan menggunakan tenaga kerja secara efisien untuk mencapai tujuan yang telah ditentukan. Empat prinsip dasar pengelolaan sumber daya manusia yaitu: (a) dalam mengembangkan sekolah, sumber daya manusia adalah komponen paling berharga; (b) sumber daya manusia akan berperan secara optimal jika dikelola dengan 
baik, sehingga mendukung tujuan institusional; (c) kultur dan suasana organisasi di sekolah, serta perilaku manajerial sekolah sangat berpengaruh terhadap pencapaian tujuan pengembangan sekolah; dan (d) pengelolaan sumber daya manusia di sekolah pada prinsipnya mengupayakan agar setiap warga dapat bekerja sama dan saling mendukung untuk mencapai tujuan sekolah (Sobri, 2009).

Menurut informan Satwika Cudhayanti (wawancara tanggal 21 Oktober 2018) menyatakan bahwa sumber daya manusia (SDM) Yayasan Pasraman Gurukula Bangli dapat dikatakan masih minim, terlihat dari jumlah tenaga pendidik dan kependidikan yang masih perlu ditambah.SDM Pasraman Gurukula terdiri dari Guru PNS, GTT daerah, Guru Pengabdi dan Pegawai Pengabdi dan Pegawai Daerah. Dimana sebagian besar adalah dari guru dan pegawai pengabdi.

\section{c. Pengelolaan Keuangan}

Pengelolaan keuangan Yayasan Pasraman Gurukula Bangli adalah tanggung jawab bersama.Hal tersebut sesuai dengan peraturan dalam undang-undang.Pendanaan pendidikan merupakan tanggung jawab bersama antara Pemerintah, Pemerintah Daerah dan masyarakat. Hal ini sesuai dengan Undang-Undang Republik Indonesia Nomor 20 Tahun 2003 tentang Sistem Pendidikan Nasional pada Bab XIII Bagian ke-1 tentang Tanggung Jawab Pendanaan pada Pasal 46 sebagai berikut :

1. Pendanaan pendidikan menjadi tanggung jawab bersama antara Pemerintah, Pemerintah Daerah dan masyarakat.

2. Pemerintah dan Pemerintah Daerah bertanggung jawab menyediakan anggaran pendidikan sebagaimana diatur dalam Pasal 31 ayat (4) Undang-Undang Dasar Negara Republik Indonesia Tahun 1945.

3. Ketentuan mengenai tanggung jawab pendanaan pendidikan sebagaimana dimaksud dalam ayat (1) dan ayat (2) diatur lebih lanjut dengan Peraturan Pemerintah

\section{d. Pengelolaan Ketatausahaan}

Sistem pengeloalaan ketatausahan pada Yayasan Pasraman Gurukula Bangli didasarkan atas sebuah proses menghimpun, mencatat, mengolah, menggandakan, mengirim 
dan menyimpan segala berkas-berkas yang berhubungan dengan berkas siswa maupun berkas guru dan yang lainnya, termasuk juga proses pembelajaran.

\section{e. Pengelolaan Hubungan Masyarakat}

Pengelolaan Pendidikan keagamaan Hindu di Yayasan Pasraman Gurukula menerapkan 2 kurikulum, yakni kurikulum Nasional (K13) dan Kurikulum Pasraman Formal dan Non formal. Pada jenjang TK (Pratama Widya Prasraman) gurukula sudah dioprasionalkan sesuai ijin oprasional Dirjen Bimas Hindu, mulai tahun ajaran 2018/2019 dengan menggunakan kurikulum Pasraman Formal. Pada jenjang SD (Adi Widya Pasrama) walaupun sudah mendapat ijin oprasional dari Dirjen Bimas Hindu RI, sudah mulai dioprasionalkan pada tahun 2018/2019. Pada jenjang SMP dan SMA masih menggunakan kurikulum nasional (K13) dengan memasukkan muatan pembelajaran keagamaan Hindu kedalam kurikulum sebanyak 20\%. Serta pembelajaran berlandaskan nilai-nilai agama Hindu.

Pada pasraman non formal sudah mendapatkan ijin dari Dirjen Bimas Hindu RI, sehingga pelaksanaan Pasraman formal sudah efektif dengan mengacu kepada kurikulum Pasraman non formal yang sudah di dokumenkan kedalam buku 1 dan 2 (KTSP) Kurikulum Tingkat Satuan Pasraman. Pembiayaan guna mengoprasionalkan pendidikan baik formal maupun non formal masih mandiri dan menggunakan bantuan dari donatur yang tidak mengikat, kecuali pembelajaran formal Kurikulum Nasional pada tingkat SMP dan SMA dibiayai dari dana BOS sesuai peraturan yang berlaku. Pembelajaran dengan menggunakan konsep Asrama, siswa di Asramakan, kusus untuk tingkat SMP dan SMA, dan yang berperan penting dalam pengelolaan pendidikan keagamaan Hindu di Yayasan Pasraman Gurukula terdiri dari semua unsur, baik unsurYayasan, Guru, pegawai, Masyarakat (umat) Pemerintah, baik pusat maupun Daerah dan juga para donatur untuk menunjang kelangsungan Hidup para siswa.

Pengelolaan TK Pratama Widya Pasraman Gurukula, di kelola oleh kepala Sekolah, di bawah binaan Yayasan Pasraman Gurukula dan Kementerian agama RI.Pengelolaan SMP dan SMA Gurukula dikelola oleh satu kepala sekolah yang di bantu oleh para Wakasek, guru, pegawai di bawah binaan Yayasan Pasraman Gurukula, Dinas pendidikan Kabupaten dan Provinsi kusus untuk tingkat SMA. Dalam kegiatan pembelajaran menggunakan Kurikulum Nasional (K13) yang didokumenkan dalam Buku 1, 2 dan 3 (KTSP), sehingga 8 standar pendidikan mengacu kepada BNSP.Pengelolaan Pasraman Gurukula yang kita sebut sekarang Pasraman non Formal dinahkodai oleh Ketua Pasraman non Formal, dengan kegiatan 
pembelajaran mengacu kepada kurikulum pasraman non formal yang di bantu oleh para Acarya, dengan biaya pendidikan (pengelolaan) masih minim bahkan belum dialokasikan baik dari pemerintah pusat maupun daerah dalam hal ini kementerian Agama.

\section{Kendala-kendala yang Dihadapi dalam Pengelolaan Pendidikan Keagamaan Hindu di Yayasan Pasraman Gurukula Bangli}

Kendala-kendala yang Dihadapi dalam Pengelolaan Pendidikan Keagamaan Hindu di Yayasan Pasraman Gurukula Bangli adalah sebagai berikut :

\section{Kendala Internal}

\subsection{Faktor Fisiologi}

Kendala internal dalam pengelolaan pendidikan keagamaan Hindu di Yayasan Pasraman Gurukula Bangli adalah adanya faktor fisiologi. Fisiologi adalah ilmu yang mempelajari tentang fungsi normal tubuh dengan berbagai gejala yang ada pada sistem hidup serta pengaturan atas segala fungsi dalam sistem tersebut. Berbagai aktivitas yang terjadi pada sistem hidup selanjutnya disebut fungsi kehidupan atau fungsi hidup.Jadi, fungsi hidup ialah fungsi sistem yang ada dalam tubuh manusia.Sistem hidup merupakan suatu yang kompleks dan bervariasi sehingga dalam fisiologi manusia,fungsi hidup adalah sesuatu yang kompleks dan bervariasi juga (Sadulloh, 2008: 97).

Berkenaan dengan hal tersebut, faktor fisiologi anak didik di Yayasan Pasraman Gurukula Bangli menjadi salah satu kendala dalam pengelolaan pendidikan keagamaan Hindu. Dalam konteks ini anak didik atau siswa dipandang sebagai manusia yang memiliki tubuh fisik dalam perkembangannya sebagai makhluk hidup. Mengacu pada teori perkembangan peserta didik, bahwa siswa sebagai peserta didik memiliki prinsip pertumbuhan dan pengembangan.

Secara emperis ada peserta didik di Yayasan Pasraman Gurukula Bangli yang mengalami gangguan fisik (fisiologi). Hal tersebut menjadi kendala tersendiri bagi siswa.Sebab cacat fisik dapat dinyatakan sebagai keterlambatan perkembangan peserta didik. Angreni (2016:19) menjelaskan bahwa keterlambatan perkembangan peserta didik berdampak pada terhambatnya proses pembelajaran. Sebagaimana penjelasan Mardita (wawancara: 20 Oktober 2018) sebagai berikut.

"Beragam kegiatan yang dilaksanakan pada pengelolaan pendidikan keagamaan di Yayasan Pasraman Gurukula Bangli.Tetapi, dalam penerapannya ada beberapa kendala yang dihadapi oleh guru dan siswa.Faktor internal berhubungan dengan aspek 
fisiologi siswa. Sebab ada siswa yang mengalami cacat fisik, yakni jalannya tidak normal, sehingga guru membutuhkan proses lebih maksimal dalam membina siswa. Biasanya pada kegiatan olahraga, seni budaya dan yoga yg menjadi tantangan bagi mereka, namun mereka tetap hadir pada setiap kegiatan, akan tetapi pada kegiatanyang lain mereka mampu melakukan dengan baik"

Berdasarkan atas uraian tersebut, dapat diketahui bahwa kendala yang dihadapi guru dan pembina pasraman dalam pengelolaan pendidikan keagamaan Hindu di yayasan Pasraman Gurukula Bangli adalah disebabkan adanya faktor fisiologis, yakni cacat fisik pada dua orang siswa. Selain ada siswa yang mengalami cacat fisik, ada pula siswa yang merupakan mantan (bekas) narapidana yang sengaja dititipkan di pasraman dengan harapan si anak dapat dididik menjadi pribadi yang benar-benar berkarakter.

Keterbatasan fisik dari peserta didik sangat memberikan pengaruh terhadap proses pembelajaran, tetapi hal tersebut menjadi "motivasi" tersendiri bagi guru sebagai pilot preject pembelajaran di Yayasan Pasraman Gurukula Bangli. Kendala fisiologis tentunya dapat ditanggulangi dengan berbagai setrategi dan pendekatan pembelajaran.

\subsection{Faktor Psikologi}

Selain faktor fisiologi yang menjadi kendala dalam pengelolaan pendidikan keagamaan Hindu di Yayasan Pasraman Gurukula Bangli adalah faktor psikologi. Piskologi adalah berhubungan dengan kondisi "psikis" atau perilaku kejiwaan peserta didik. Faktor kondisi psikis amat penting sebagai penentu berhasil dan tidaknya proses pembelajaran. Kebanyakan siswa terkadang bahkan sering tidak menyukai aktivitas keagamaan, sehingga pembelajaran justru menjadi mereka terbebani. Sedangkan menyitir asumsi nya Artjumsai (1999: 97), dalam tesanya tentang Pendidikan Nilai-Nilai Kemanusiaan atau The Human Values Education menjelaskan bahwasanya pembelajaran harus menyenangkan dan mendidik, bukan membebani tetapi diktator.

\section{Kendala Eksternal}

Kendala lainnya selain adanya faktor internal adalah adanya kendala dari eksternal.Kendala eksternal juga tidak dapat diabaikan begitu saja, sebab kendala eksternal merupakan faktor yang penghambat pengelolaan pendidikan keagaman Hindu di Yayasan Pasraman Gurukula Bangli. Kendala eksternal sudah pasti berhubungan dengan hal-hal yang sifatnya luaran dari siswa sebagai peserta didik dalam proses pembelajaran di pasraman. Kendala eksternal bisa saja muncul dari SDM (sumber daya manusia) dalam konteks ini tentunya merujuk pada SDM Guru atau acarya sebagai manusia pendidik atau mendidik. 
Selain guru, sarana dan prasarana pembelajaran sebagai pelengkap pembelajaran juga sangat menentukan berhasil dan tidaknya proses pembelajaran (Sutirna, 2015). Demikian pula faktor pendanaan sangat berperanan penting dalam sebuah pengelolaan.

\section{Upaya-upaya yang Dilakukan untuk Mengatasi Kendala-Kendala dalam Pengelolaan Pendidikan Keagamaan Hindu di Yayasan Pasraman Gurukula Bangli}

Upaya-upaya yang Dilakukan untuk Mengatasi Kendala-Kendala dalam Pengelolaan Pendidikan Keagamaan Hindu di Yayasan Pasraman Gurukula Bangli adalah sebagai berikut :

\section{Kerja Keras dan Semangat Stakeholder}

Upaya yang dilakukan selama ini oleh segenap unsur pengelola Yayasan Pasraman Gurukula Bangli dalam mengatasi kendala-kendala yang dihadapi dalam pengelolaan pendidikan agama Hindu adalah bekerja keras dalam memafaatkan stakeholder. Sebagaimana uraian Sukardjo (2017: 34), bahwa stakeholder pendidikan dapat diartikan sebagai orang yang menjadi pemegang dan sekaligus pemberi support terhadap pendidikan atau lembaga Pendidikan. Sebagai lembaga pendidikan yang berbasis agama Hindu, dan satu-satunya dalam bentuk pasraman, Yayasan Pasraman Gurukula Bangli sesungguhnya memiliki stakeholder yang banyak untuk membangun alur koordinasi dan sinergitas dengan berbagai lembaga terkait.Namun di sini yang dibutuhkan adalah kerja keras dalam mebangun dan mencari stakeholder dengan memberikan contoh nyata, baik lulusan dan kemampuan yayasan dalam mebangun atmosfir pembelajaran yang khas dan mengacu pada ajaran agama Hindu.

\section{Kerjasama dengan Pihak Lain}

Selain stakeholder dapat dijalin dengan para pemegang modal, kerjasama juga hendaknya dibangun dengan pemerintah dan lembaga terkait sebagai pemegang kebijakan, baik kebijakan yang menyoal tentang pendanaan dan yang lainnya. Sebagaimana uraian Eka Putra (Wawancara, 20 Oktober 2018), bahwasanya terkait dengan masalah pembiayaan, walaupun masih belum maksimal tidak membuat mutu pendidikan di Yayasan Pasraman Gurukula Bangli semakin menurun, namun masih bisa meningkatkan prestasi peserta didiknya, baik dalam bidang kognitif, afektif dan psikomotor. Hal ini dikarenakan upaya yang dilakukan dengan kerja keras dan semangat stakeholder dalam mengelola lembaga ini. Dalam pengelolaan lembaga ini, pembiayaan yang digunakan tidak hanya berbentuk uang saja, 
melainkan tenaga yang bisa membantu proses pelaksanaan pendidikan, khususnya pendidikan agama Hindu. Misalnya tenaga kerja relawan yang siap meluangkan waktu untuk memberikan materi-materi dan pengalaman-pengalam yang mendukung. Tenaga relawan yang sering membantu dalam pembinaan tidak hanya relawan lokal, namun dari organisasi tertentu, bahkan relawan dari luar negeri. Untuk menarik simpati para donator maupun relawan tersebut, maka perlu penampilan, sikap dan lingkungan yang menarik dari siswa.

\section{Permohonan Bantuan ke Pihak Terkait}

Selain upaya tersebut di atas, upaya berikutnya yang penting juga untuk dilakukan oleh Yayasan Pasraman Gurukula Bangli adalah melakukan permohonan bantuan dana pendidikan ke semua pihak yang tentunya terkait dengan pengembangan pengelolaan pendidikan dan kebudayaan. Adapun pihak terkait yang penting untuk diajak kerjasama adalah pihak sosial yang berkontribusi terhadap perkembangan pendidikan.

\section{Mengundang Orang Tua Siswa}

Dalam pelaksanaan pendidikan pasraman yang selama ini di Yayasan Pasraman Gurukula Bangli selalu memiliki hubungan yang koheren dengan aspek sosio religius dan melibatkan peran serta orang tua sebagai wali murid.Orang tua menjadi sangat penting untuk mengetahui program pada lembaga pendidikan formal dan non formal yang berlangsung di Yayasan Pasraman Gurukula Bangli.Sebagaimana dijelaskan dalam uraian informan Juta Ningrat (wawancara, 20 Oktober 2018) sebagai berikut.

"Upaya yang dilakukan untuk hambatan-hambatan dalam pengelolaan adalah meningkatkan kerja sama antara orang tua siswa dengan sekolah. di Pasraman Gurukula, orang tua diundang oleh lembaga pada waktu kegiatan sekolah, seperti penerimaan raport, pelaksanaan hari Saraswati dan penerimaan siswa baru, untuk melakukan diskusi dan laporan tentang perkembangan peserta didik. Untuk orang tua yang memiliki anak masih belum ada perkembangan dipanggil secara khusus untuk melakukan pembinaan bersama."

Kerjasama yang melibatkan orang tua siswa dengan lembaga pendidikan sangat penting sebagai upaya untuk menemukan berbagai solusi terkait dengan segala kendala dan permasalahan yang terjadi di sekolah.Peran orang tua dalam perkembangan anak sangat krusial (Rahmat, 2017). Berbagai penelitian menunjukkan bahwa pencapaian pelajar meningkat jika orang tua mengambil peran aktif dalam pendidikan anak-anak didik mereka.Salah satunya ditunjukkan oleh hasil penelitian Harvard Family Research Project's (HFRP) dan dikutip dari 
pendapatnya Hamallik (2006: 67), yang memperlihatkan bahwa keterlibatan orangtua memiliki kaitan erat dengan hasil prestasi anak. Penemuan ini secara konsisten telihat, pada indikasiindikasi kesuksesan anak, apakah itu nilai, skor tes yang memiliki standar, atau metode pengukuran lain termasuk penilaian guru.Itulah sebabnya sekolah yang baik adalah sekolah yang memberikan tempat bagi orang tua untuk ikut terlibat dalam pendidikan anak-anak mereka. Bagaimana orang tua anak melibatkan diri adalah faktor kunci dalam meningkatkan prestasi anak dan juga menjaga kedewasaan mentalnya(Sutriyanti, 2016).

\section{Simpulan}

Pengelolaan Pendidikan keagamaan Hindu di Yayasan Pasraman Gurukula Bangli meliputi beberapa hal, yakni: 1) Pengelolaan kurikulum yang terintegrasi antara kurikulum Nasional dengan kurikulum Pasraman, 2) Pengelolaan siswa yang di dalamnya ada penerimaan siswa, pencatatan di dalam buku induk, kemajuan pembelajaran dan bimbingan dalam hal pendisiplinan belajar dan etika tentunya, 3) Pengeloalaan SDM yang meliputi beberapa hal yang terkait dalam pengembangan dan pelatihan melalui pendidikan agama Hindu, 4) Pengeloalaan sarana dan prasarana sesuai dengan kebutuhan, 5) Pengeloalan ketatausahaan yang melibatkan pegawai tatausaha dalam mengelola, 6) Pengelolaan hubungan masyarakat.

Kendala-Kendala yang dihadapi dalam pengelolaan pendidikan keagamaan Hindu di Yayasan Pasraman Gurukula Bangli meliputi beberapa hal: 1) Kendala Internal yang di dalamnya ada faktor fisiologi dan psikologi, 2) Kendala Eksternal meliputi beberapa hal seperti: pendanaan, sumber daya manusia dan sarana prasarana. Upaya yang dilakukan dalam mengatasi kendala yang dihadapi dalam pengelolaan pendidikan keagamaan Hindu di Yayasan Pasraman Gurukula Bangli, yakni: 1) Kerja keras dan membangun jaringan dengan stakehoders, 2) Kerjasama dengan pihak lain dan terkait dalam membangun sinergitas yang kuat, 3) Mensosialisasikan Yayasan pasraman Gurukula Bangli sebagai lembaga pendidikan agama Hindu dengan segala keunggulannya, 4) Permohonan bantuan kepada pihak terkait, meskipun lembaga pendidikan pasraman bersifat non profit, dan 5) Mendatangkan orang tua siswa dalam bentuk kerjasama, sebab peran mereka juga sangat penting dalam proses pembelajaran.

\section{DAFTAR PUSTAKA}

Rahmat, P. S. (2017). Psikologi Pendidikan. Kuningan: Bumi Aksara. 
Rusman. (2011). Model-Model Pembelajaran. Jakarta: PT Rajindo Persada.

Sobri. (2009). Pengelolaan Pendidikan. Yogyakarta, Indonesia: Multi Pressindo.

Suda, I. K. (2017). Pasraman Sebagai Energi Pendidikan Agama Dan Seni Hindu Dalam Dominasi Dan Hegemoni Pendidikan Modern. Soshum: Jurnal Sosial Dan Humaniora. https://doi.org/10.31940/soshum.v7i3.714

Sukardjo. (2013). Landasan Pendidikan Konsep dan Aplikasi. Jakarta: Rajawali Pers.

Sutirna. (2015). Landasan Pendidikan. Bandung: PT. Refika Aditama.

Sutriyanti, N. K. (2016). Peningkatan Mutu Pendidikan Karakter Melalui Peran Orang Tua Dalam Keluarga. Jurnal Penjaminan Mutu. https://doi.org/10.25078/jpm.v2i1.57

Sutriyanti, N. K. (2017). Implementasi Kurikulum 2013 Pada Pembelajaran Pendidikan Agama Hindu Tingkat Sekolah Dasar Di Kota Denpasar. Vidya Samhita. 